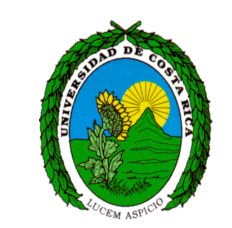

\title{
EKG 3-2014: Marcapaso Migratorio.
}

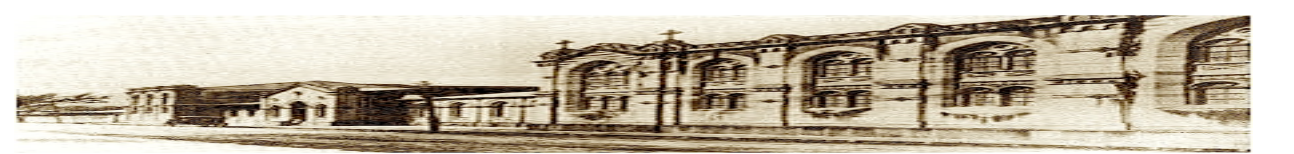

ISSN 2215-741

Haspital San Duan de Dias, San Dosé. Costa Rica. Fundado en 1845
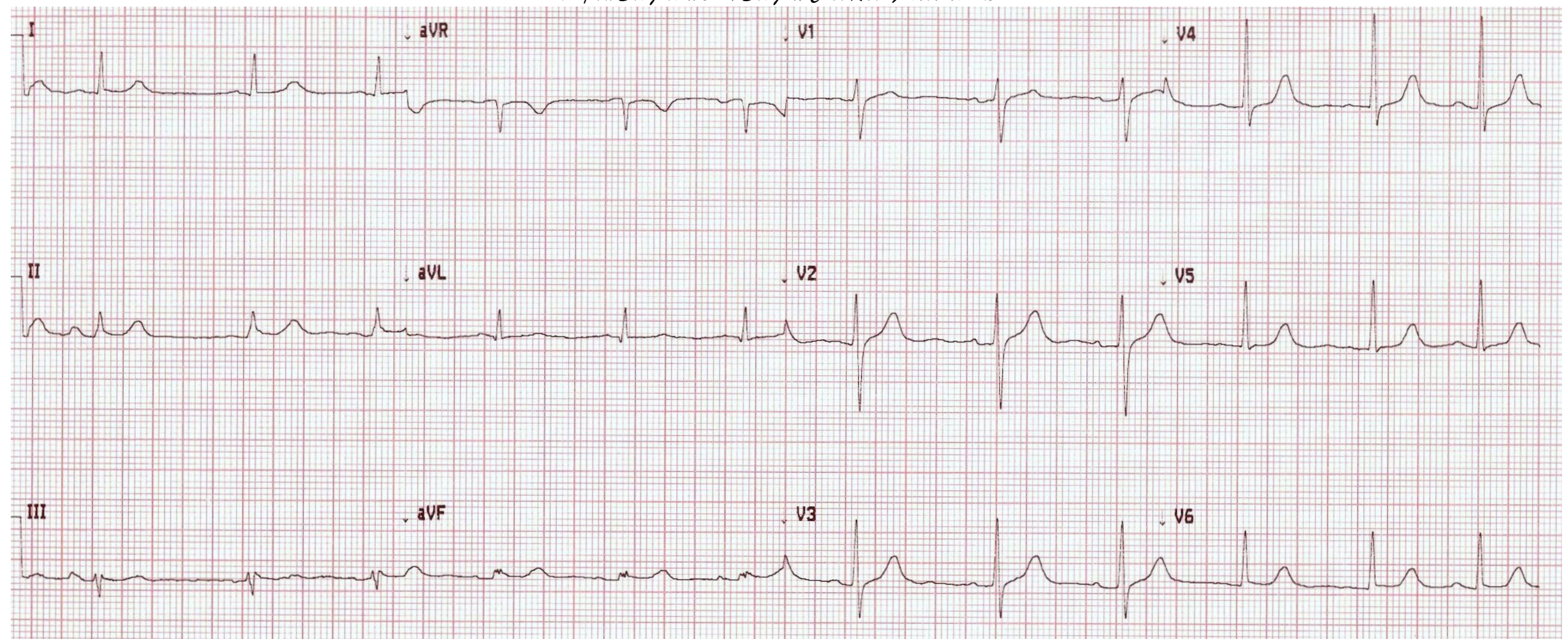